\title{
Gall-inducing arthropods in a Neotropical savanna area in the EPA of Rio Pandeiros (Bonito de Minas, MG, Brazil): effects of plant species richness and super-host abundance
}

\author{
Walter Santos de Araújo ${ }^{1,4}$; Kelly Christie dos Santos Costa ${ }^{1,5}$; Luana Teixeira Silveira ${ }^{2,6}$; Érica Vanessa Durães de Freitas ${ }^{2,7}$; \\ Yule Roberta Ferreira Nunes ${ }^{1,8}$ \& Islaine Franciely Pinheiro de Azevedo, ${ }^{3,9}$
}

1 Universidade Estadual de Montes Claros (UNIMONTES), Centro de Ciências Biológicas e da Saúde (CCBS), Departamento de Biologia Geral. Montes Claros, MG, Brasil.

2 Universidade Estadual de Montes Claros (UNIMONTES), Programa de Pós-Graduação em Biodiversidade e Uso dos Recursos Naturais (PPG-BURN). Montes Claros, MG, Brasil.

3 Universidade Estadual de Montes Claros (UNIMONTES), Programa de Pós-Graduação em Botânica Aplicada (PPG-BOT). Montes Claros, MG, Brasil.

${ }^{4}$ ORCID: http://orcid.org/0000-0003-0157-6151. E-mail: walterbioaraujo@yahoo.com.br (corresponding author)

${ }^{5}$ ORCID: http://orcid.org/0000-0001-6156-0720. E-mail: christiekelly96@gmail.com

${ }^{6}$ ORCID: http://orcid.org/0000-0002-2428-7435. E-mail: luanat.silveira@hotmail.com

7 ORCID: http://orcid.org/0000-0003-1303-2899. E-mail: vanessaduraesfreitas@gmail.com

${ }^{8}$ ORCID: http://orcid.org/0000-0003-3328-7506. E-mail: yule.rfnunes@gmail.com

${ }^{9}$ ORCID: http://orcid.org/0000-0002-8078-6423. E-mail: islaazevedo@yahoo.com.br

\begin{abstract}
Several plant-related factors can influence the diversity of gall-inducing species communities. In the present study we performed an inventory of gall-inducing arthropods and we tested if the plant species richness and the abundance of superhost plants (Copaifera oblongifolia) influenced positively in the diversity of gall-inducing arthropod species. The study was realized in an area of Neotropical savanna (cerrado sensu stricto) in the Environmental Protection Area (EPA) of Rio Pandeiros, Minas Gerais, Brazil. Host-plant species and gall-inducing arthropods were sampled in $1810 \times 10 \mathrm{~m}$ plots distributed in the vegetation. In total we found 40 arthropod gall morphotypes, distributed on 17 botanical families and 29 plant species. Cecidomyiidae (Diptera) induced the most arthropod galls (85\%), and the plant family Fabaceae had the greatest richness of gall morphotypes (16). The plant species Copaifera oblongifolia and Andira humilis (Fabaceae) were the most important host species with five and three morphotypes, respectively. Galling species richness was not affected by none of explanatory variables (plant species richness and abundance of super-host plants). On the other hand, galling species per plant species was negatively affected by plant species richness and positively affected by abundance of super-host plants. This is the first study of arthropod-induced galls conducted in EPA of Rio Pandeiros, Brazil. Our results corroborate previous studies that highlight the importance of super-host plants for galling arthropod diversity on a local scale.
\end{abstract}

Key-Words. Arthropod-plant interactions; Cecidomyiidae; Cerrado; Copaifera; Fabaceae.

\section{INTRODUCTION}

Plant-animal interactions between herbivorous arthropods and their host plants encompass the greatest diversity of terrestrial species (Price, 2002). Among herbivorous arthropods, gall-inducing species represent the most specialized guild (Araújo et al., 2019a), because they are the only arthropods capable of manipulating physiological and anatomical plant structures inducing the formation of galls (review in Miller III \& Raman, 2019). Arthropod galls are structures formed by hyperplasia and hypertrophy of plant tissues, inside which the inductor development and feed (Fernandes et al., 2014). In addition, galls can provide shelter for galling arthropods against attack by natural enemies and environmental weathering (Miller III \& Raman, 2019). Due to the intimate association between gall-inductors and their host plants, galling arthropod communities tend to be strongly influenced by host plant assemblages (Araújo et al., 2013; Altamirano et al., 2016; Costa \& Araújo, 2019).

One of the main factors of plant assemblages that can influence galling communities is the richness of plant species (review in Araújo, 2013). Plant species richness represents a greater di- 
versity of resources for the use of gall-inducing species (Cuevas-Reyes et al., 2004). In this sense, several evidences point that gall-inducing species richness increases as more potential host plant species are available (e.g., Wright \& Samways, 1998; Gonçalves-Alvim \& Fernandes, 2001; Cuevas-Reyes et al., 2004). On the other hand, there is also evidence that some galling communities are little influenced by richness of plant communities, because plant species vary greatly in their susceptibility to gall induction (Blanche, 2000; Araújo et al., 2013).

In tropical environments, many plant species have few or no gall-inducing species (Blanche, 2000), but some plant species can host many species of galling arthropods (Araújo et al., 2013). The existence of super-host plants, i.e., plant species with a high number of gall-inducing species, indicates that the composition of plant assemblages also is important for the galling community (Araújo et al., 2013). Therefore, the occurrence of super-host plants may increase the diversity of arthropod galls, regardless of the number of plant species (Veldtman \& McGeoch, 2003; Araújo et al., 2014a). For Brazilian savannas, some super-host plants are recorded, such as Baccharis dracunculifolia DC. (Fernandes et al., 1996), Copaifera langsdorffii Desf. (Costa et al., 2010; Ribeiro et al., 2019), and Qualea parviflora Mart. (Araújo et al., 2013), but few studies have investigated the effect of the presence of these taxa on the local diversity of galling species.

In the present study we performed an inventory of gall-inducing arthropods and their host plants in an area of Neotropical savanna (cerrado sensu stricto) located in the Environmental Protection Area (EPA) of Rio Pandeiros (Bonito de Minas, MG, Brazil). Additionally, we tested if the plant species richness and the abundance of super-host plants influenced positively in the diversity of gall-inducing arthropod species.

\section{MATERIAL AND METHODS}

\section{Study area}

The study was performed in an area of Neotropical savanna (cerrado sensu stricto) in the Environmental Protection Area (EPA) of Rio Pandeiros (15'21'37.2"S and $44^{\circ} 54^{\prime} 45.9^{\prime \prime} \mathrm{W}$ ), which englobe the municipalities of Bonito de Minas, Cônego Marinho and Januária in the North of Minas Gerais State, Brazil. The reserve has an area of 431.401 hectares and was created in 1995 with objective to preserve the hydric resources and biodiversity in the valley of Pandeiros river. This area has been classified as of extreme biological importance, priority for scientific research and biodiversity conservation (Drummond et al., 2005). The EPA of Pandeiros river is located in an ecotone zone between the domains of Caatinga and Cerrado and has a remarkable floristic diversity, characteristic of this transitional effect (Bahia et al., 2009; Fagundes et al., 2019a). The cerrado sensu stricto is the predominant physiognomy of the EPA, but seasonally dry tropical forest and palm swamps are very common in the area (Bahia et al., 2009). Soils are classified as Quartzarenic Neosol, with sandy texture, Dystrophic Haplic Cambisol and Latosol with high water storage capacity, acid and low fertility (EMBRAPA, 2013). The climate of the region is tropical dry (Aw in the Köppen system), characterized by well-defined rainy periods, an average temperature of $24.2^{\circ} \mathrm{C}$, and an average annual rainfall of $1,000 \mathrm{~mm}$ (Alvares et al., 2013).

\section{Arthropod gall survey}

Arthropod gall sampling was performed in a rapid ecological study realized in November of 2019. The sampling was realized in 18 plots of $10 \times 10 \mathrm{~m}$ distributed in the study area (Araújo et al., 2013). In each plot all woody plants with a circumference $\geq 10 \mathrm{~cm}$ at $1.3 \mathrm{~m}$ above ground were sampled. The botanical material was herborized and identified according to the botanical literature and/or the recommendation of experts. In the plots arthropod galls were sampled by active searches up to a height of $2.5 \mathrm{~m}$ in all plants. All sampled galls were classified into morphotypes using the host plant species and external morphology (organ of occurrence, shape, color, pubescence and size) (Carneiro et al., 2009). To designate gall morphotypes we use the terminology proposed by Isaias et al. (2013). Gall-inducing arthropods were determined from dissection of galls in field or laboratory and also using the arthropod gall literature from Neotropic and Brazil (e.g., Maia \& Fernandes, 2004; Carneiro et al., 2009; Gagné, 2014; Araújo et al., 2013; Araújo et al., 2014b; Araújo et al., 2019b). In the area, we recorded the host-plant species Copaifera oblongifolia DC. (Fabaceae), which has been recently listed as a super-host plant harboring 15 different species of gall-inducing insects (Coutinho et al., 2019).

\section{Statistical analyses}

For the statistical analyses, galling species richness (total number of arthropod gall morphotypes in each plot) and galling species per plant species (mean number of arthropod gall morphotypes by host plant species in each plot) were used as response variable. We used the plant species richness and abundance of super-host plants as explanatory variables at plot level in generalized linear models (GLM's) built for each response variable. In the present study we used the abundance of Copaifera oblongifolia as a measure of abundance of super-host plants. All models were submitted to a residual analysis to determine the adequacy of error distribution and had a Gaussian error distribution assumed. All statistical analyses were performed in the software $\mathrm{R}$ version 3.4.1 (R Development Core Team, 2015).

\section{RESULTS}

We found a total of 40 arthropod gall morphotypes distributed on 29 species and 17 families of host-plants in the study area (Table 1; Figs. 1-5). The mean number 


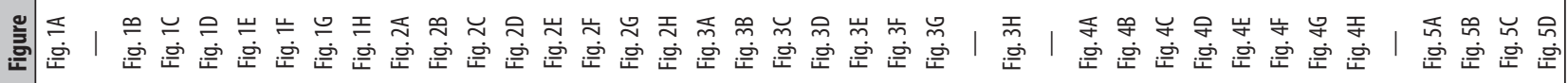

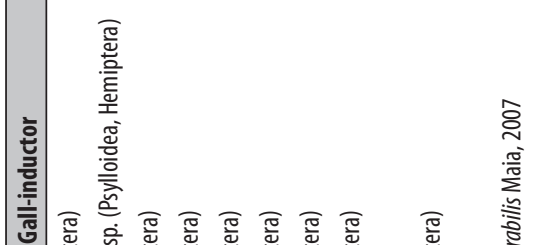

亏े

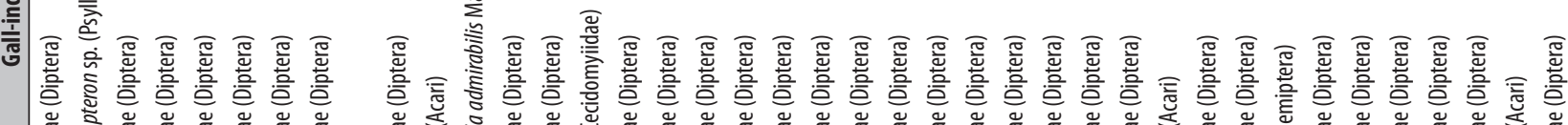

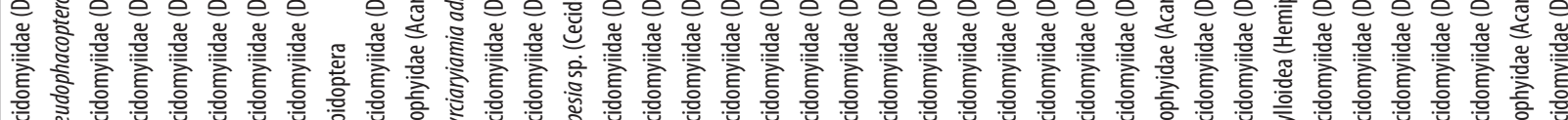

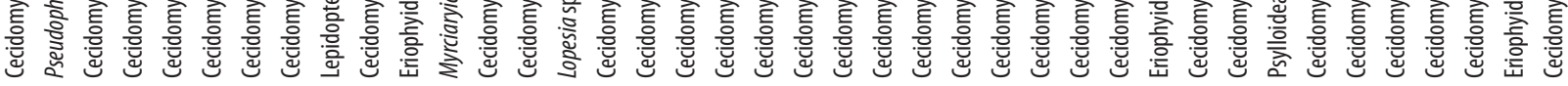

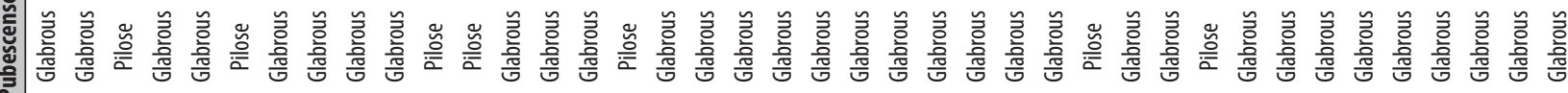

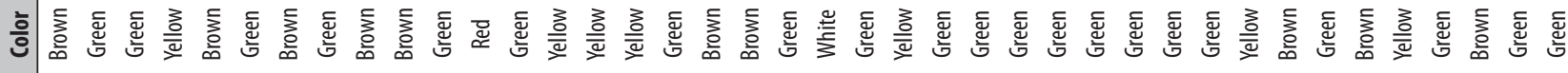

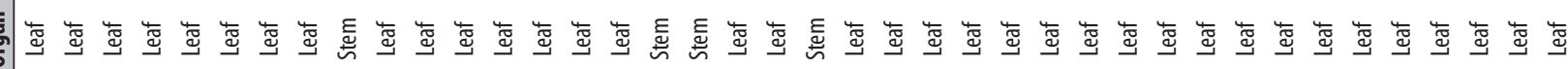

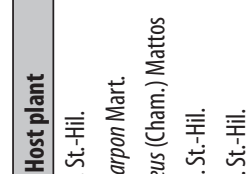

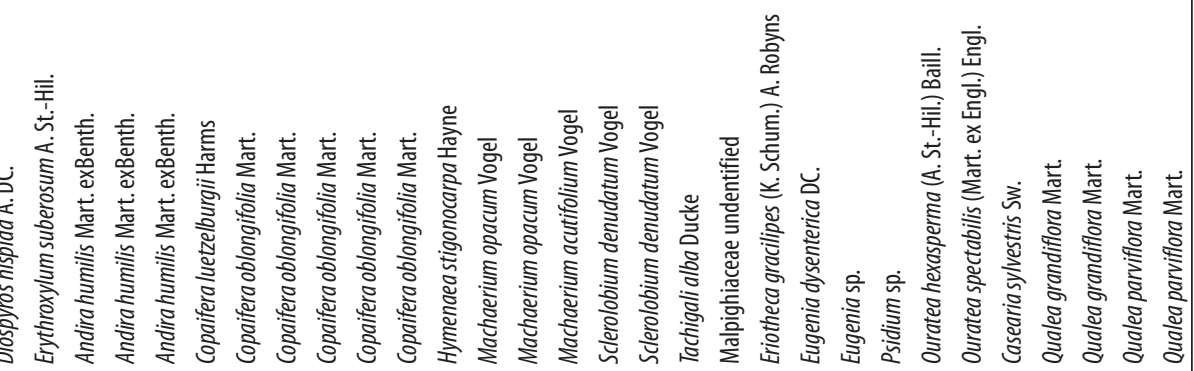

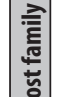

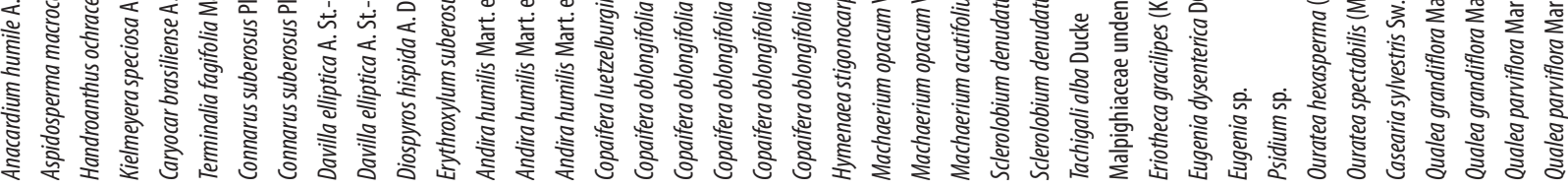



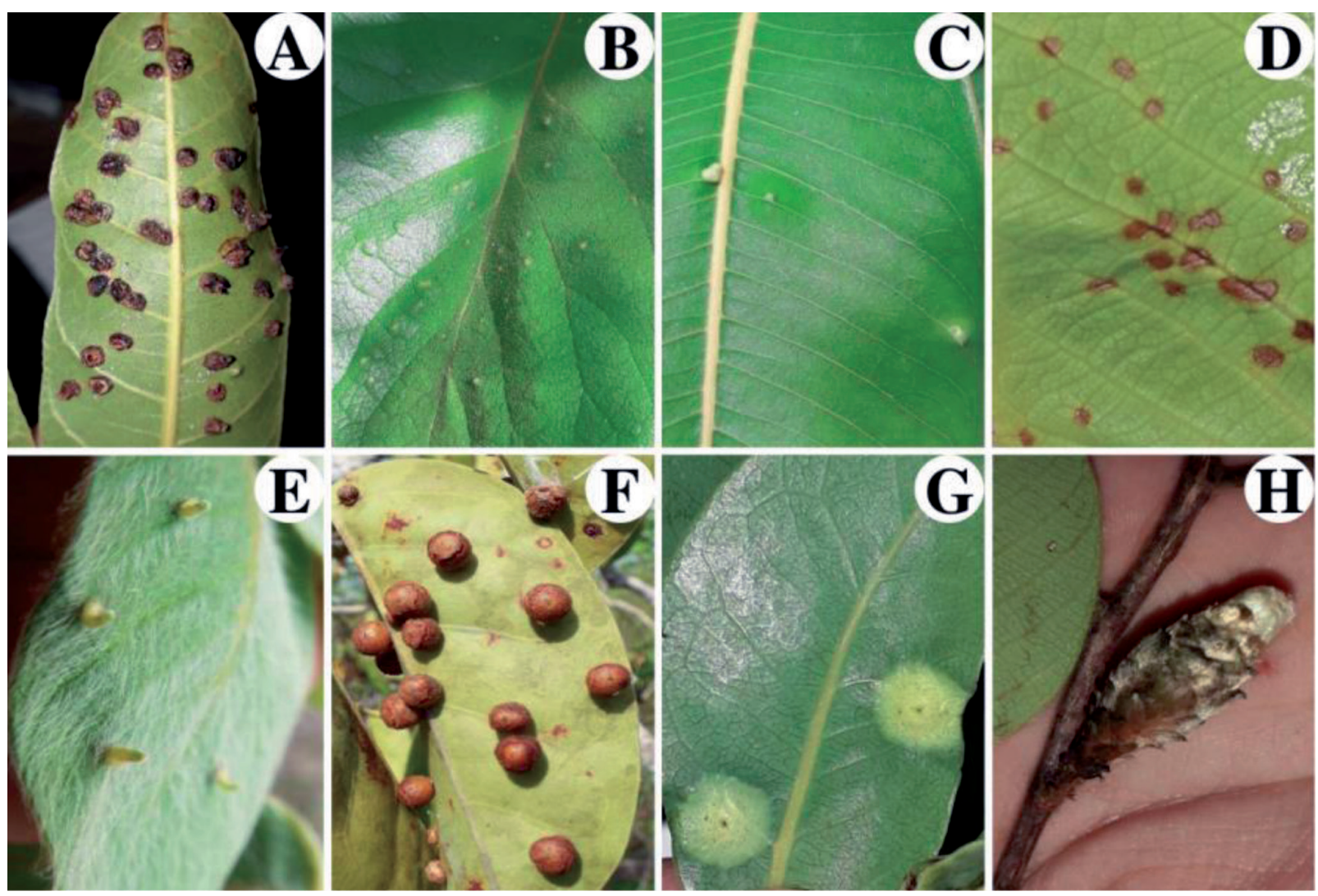

Figure 1. Gall morphotypes in host plants in an area of Neotropical savanna in the EPA of Rio Pandeiros (Bonito de Minas, MG, Brazil). (A) Anacardiaceae $=$ Anacardium humile, (B) Bignoniaceae $=$ Handroanthus ochraceus, (C) Calophyllaceae $=$ Kielmeyera speciosa, $(\mathrm{D})$ Caryocaraceae $=$ Caryocar brasiliense, $(\mathrm{E})$ Combretaceae $=$ Terminalia fagifolia, $(\mathrm{F}-\mathrm{G})$ Connaraceae $=$ Connarus suberosus, $(\mathrm{H})$ Dilleniaceae $=$ Davilla elliptica.
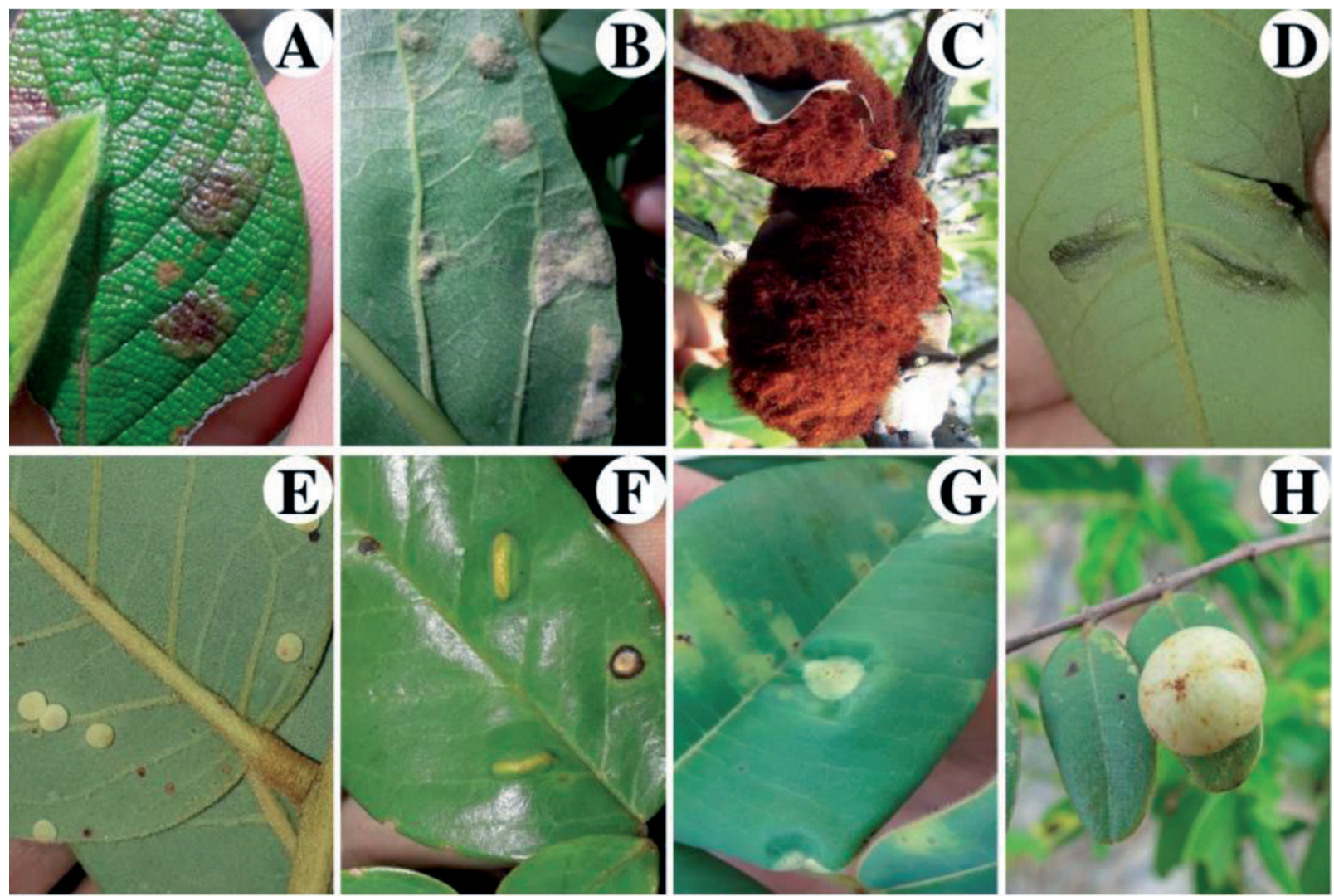

Figure 2. Gall morphotypes in host plants in an area of Neotropical savanna in the EPA of Rio Pandeiros (Bonito de Minas, MG, Brazil). (A) Dilleniaceae = Davilla elliptica, (B) Ebenaceae $=$ Diospyros hispida, (C) Erythroxylaceae $=$ Erythroxylum suberosum, (D-F) Fabaceae $=$ Andira humilis, (G) Fabaceae $=$ Copaifera luetzelburgii, (H) Fabaceae $=$ Copaifera oblongifolia. 

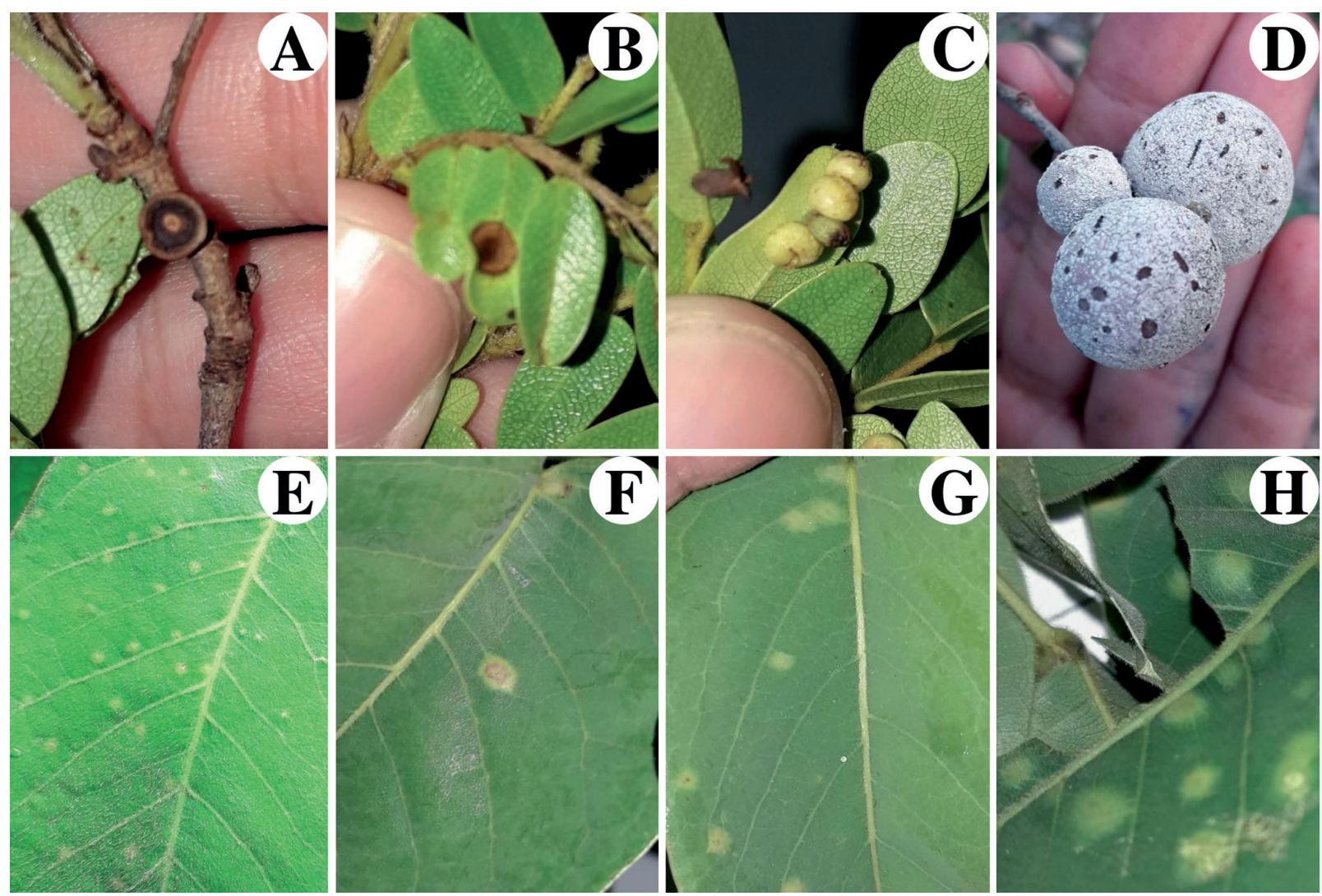

Figure 3. Gall morphotypes in host plants in an area of Neotropical savanna in the EPA of Rio Pandeiros (Bonito de Minas, MG, Brazil). (A-D) Fabaceae = Copaifera oblongifolia, $(\mathrm{E})$ Fabaceae $=$ Hymenaea stigonocarpa, $(\mathrm{F}-\mathrm{G})$ Fabaceae $=$ Machaerium opacum, $(\mathrm{H})$ Fabaceae $=$ Sclerolobium denudatum .
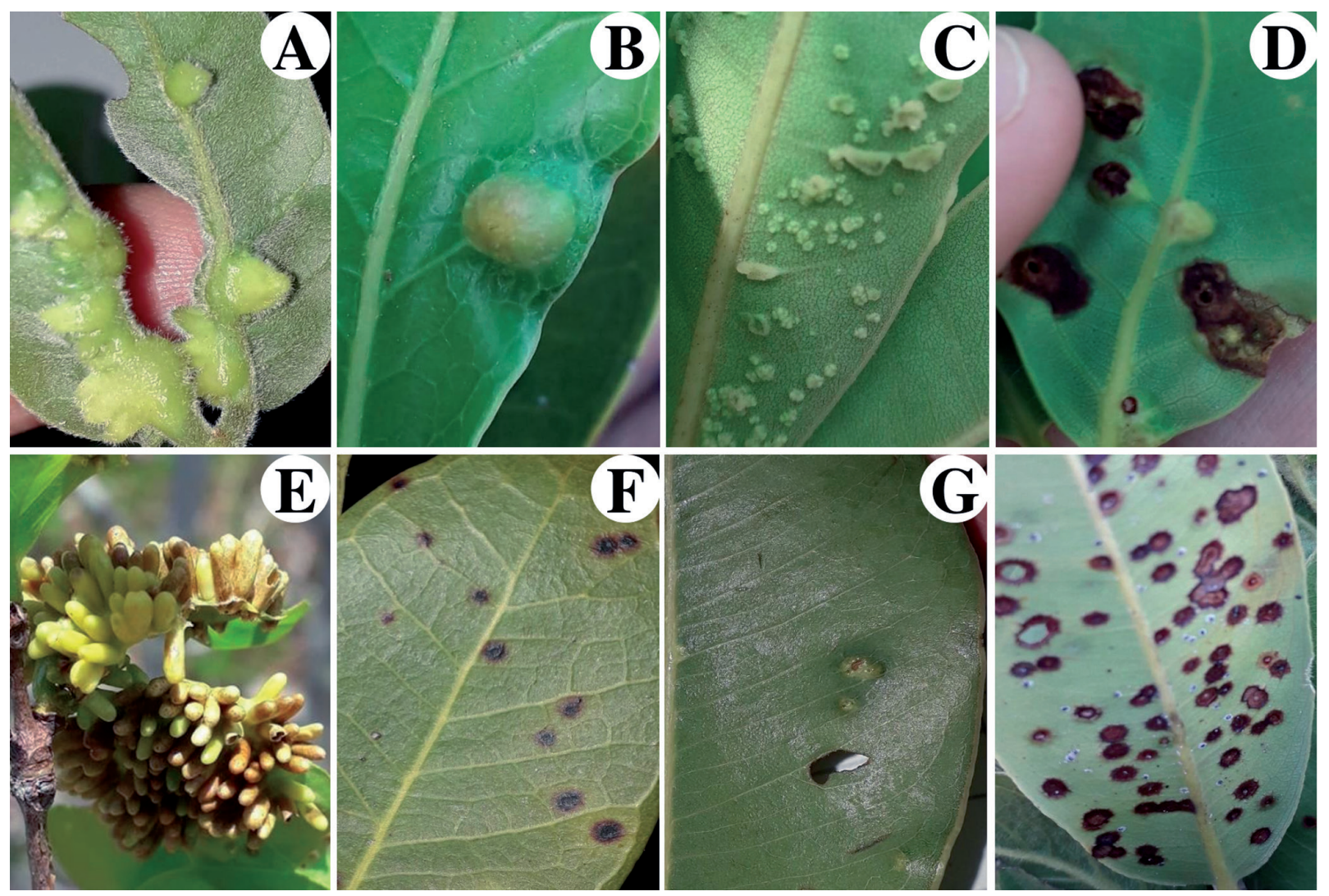

Figure 4. Gall morphotypes in host plants in an area of Neotropical savanna in the EPA of Rio Pandeiros (Bonito de Minas, MG, Brazil). (A) Fabaceae = Tachigali alba, (B) Malpighiaceae $=$ Malpighiaceae sp., (C) Malvaceae $=$ Eriotheca gracilipes, (D) Myrtaceae $=$ Eugenia dysenterica, (E) Myrtaceae $=$ Eugenia sp., (F) Myrtaceae $=$ Psidium sp., (G) 0chnaceae $=$ Ouratea hexasperma, $(\mathrm{H})$ 0chnaceae $=$ Ouratea spectabilis. 

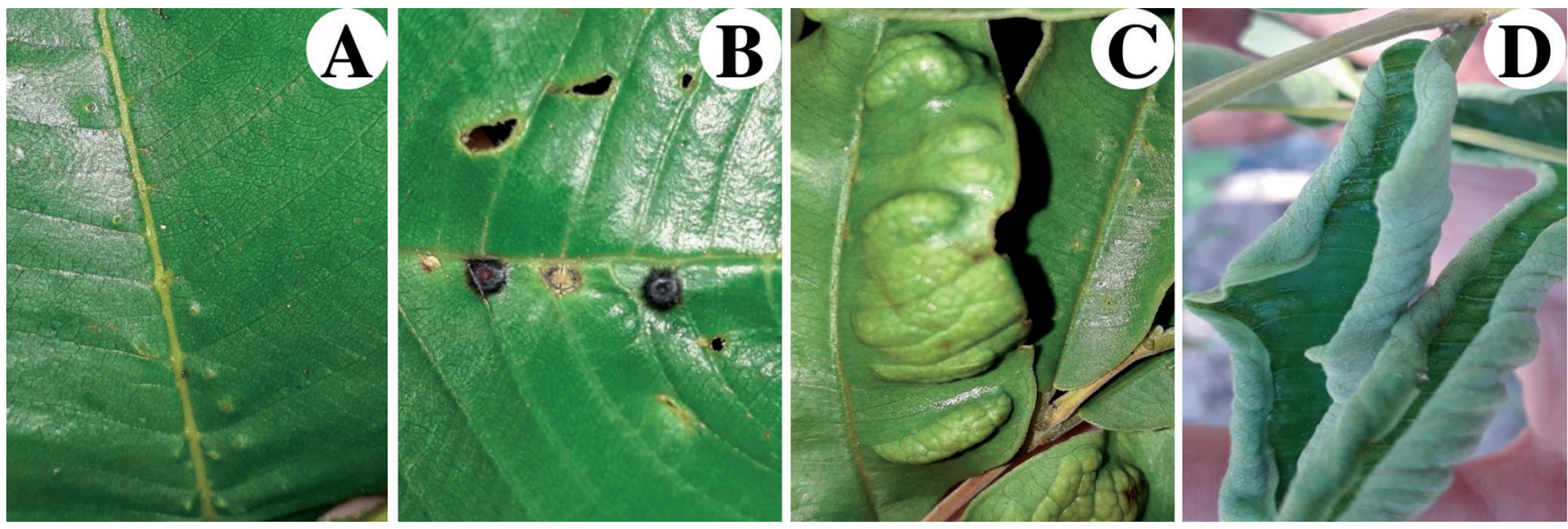

Figure 5. Gall morphotypes in host plants in an area of Neotropical savanna in the EPA of Rio Pandeiros (Bonito de Minas, MG, Brazil). (A-B) Vochysiaceae = Qualea grandiflora, (C-D) Vochysiaceae $=$ Qualea parviflora.

of gall morphotypes per host plant species was 1.37 . Gall-inducing arthropods belonged to Acari, Diptera, Hemiptera and Lepidoptera. The most important gall-inducing arthropods were Cecidomyiidae (Diptera) having induced 34 (85.0\%) gall morphotypes. In the sequence were Eriophyidae (Acari) inducing three (7.5\%) morphotypes, Psylloidea (Hemiptera) inducing two (5.0\%) morphotypes, and Lepidoptera inducing a single (2.5\%) morphotype.

The plant families that showed the greatest richness of arthropod galls were Fabaceae, with 16 (40.0\%) morphotypes, Vochysiaceae with four (10.0\%) and Myrtaceae (7.5\%) with three morphotypes (Table 1). The plant species Copaifera oblongifolia and Andira humilis Mart. ex Benth. (Fabaceae) were the most important host species with five and three morphotypes, respectively. All other host plant species had two or one morphotypes (Table 1). Most of the arthropod galls occurred on leaves $(90.0 \%)$, and was lenticular (45.0\%), green $(52.5 \%)$ and glabrous (82.5\%).

Galling species richness was not affected by none of explanatory variables (Table 2), despite the tendency of a positive effect of abundance of super-hosts on the gall richness $(p=0.057)$. Already the galling species per plant

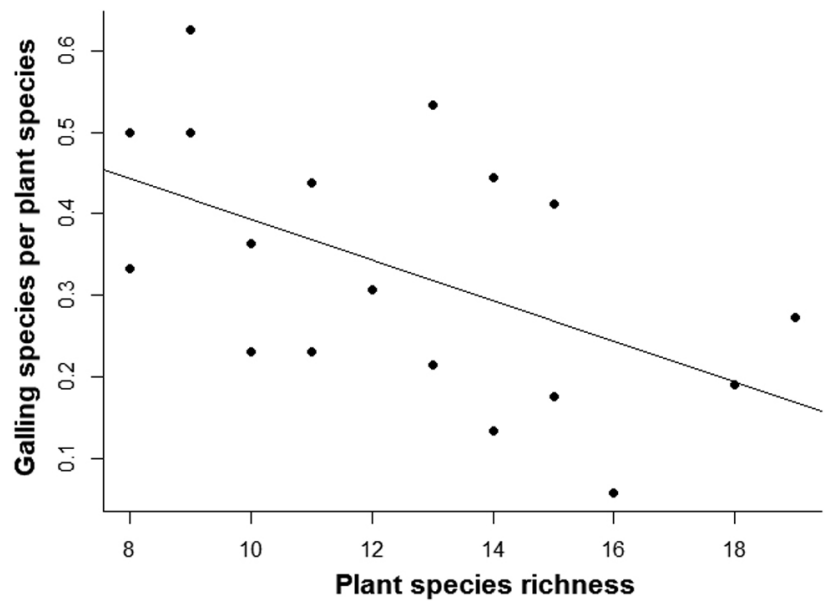

Figure 6. Effect of plant species richness on the galling species per plant species in an area of Neotropical savanna in the EPA of Rio Pandeiros (Bonito de Minas, MG, Brazil). species was significantly influenced both by plant species richness $(p=0.011)$ and abundance of super-host plants $(p=0.020)$ (Table 2). We found that galling species per plant species was negatively affected by plant species richness (Fig. 6) and positively affected by abundance of super-host plants (Fig. 7).

\section{DISCUSSION}

The number of galling species observed in the area of EPA of Rio Pandeiros (40 morphotypes) is intermediary compared to other studies performed in Neotropical savannas (Table 3). For example, Urso-Guimarães etal. (2003) recorded only 22 gall morphotypes in cerrado fragments, rupestrian field and gallery forest in Delfinópolis, Minas Gerais State. In other study, Maia \& Fernandes (2004) recorded 137 morphotypes of insect galls in an area of rupestrian fields and cerrado in the Serra de São José, Minas Gerais. These numbers extremely variable in the diversity of galling species can be explained by several factors, among which are different sampling efforts employed in the studies, as well as variations in the structural characteristics and diversity of the studied vegetation. The stan-

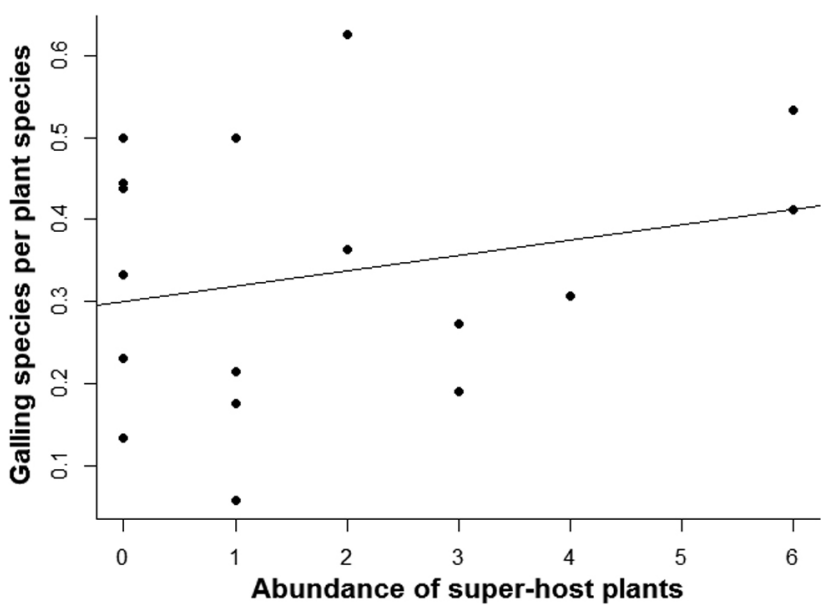

Figure 7. Effect of abundance of super-host plants on the galling species per plant species in an area of Neotropical savanna in the EPA of Rio Pandeiros (Bonito de Minas, MG, Brazil). 
Table 2. Generalized linear models testing for effects of explanatory variables (plant species richness and abundance of super-host plants) on diversity of gall-inducing arthropods (galling species richness and galling species per plant species) in a Neotropical savanna area in the EPA of Rio Pandeiros (Bonito de Minas, MG, Brazil).

\begin{tabular}{|c|c|c|c|c|c|c|}
\hline Response variables & Explanatory variables & Deviance Resid. & Df & Resid. Dev & $F$-value & $p$-value \\
\hline \multirow[t]{2}{*}{ Galling species richness } & Plant species richness & 1.660 & 16 & 94.840 & 0.337 & 0.570 \\
\hline & Abundance of super-host plants & 20.943 & 15 & 73.898 & 4.251 & 0.057 \\
\hline \multirow[t]{2}{*}{ Galling species per plant species } & Plant species richness & 0.114 & 16 & 0.296 & 8.401 & 0.011 \\
\hline & Abundance of super-host plants & 0.092 & 15 & 0.204 & 6.784 & 0.020 \\
\hline
\end{tabular}

Values of $F$ and $p$ are those of the regression coefficients in the general model.

Table 3. Richness of insect gall morphotypes, host plant species and host plant families and mean number of galls per host plant species in different localities of the Brazilian Cerrado.

\begin{tabular}{lcccc}
\hline \multicolumn{1}{c}{ Locality } & Richness of insect gall morphotypes & Richness of host plant species & Number of host plant families & Reference \\
\hline EPA of Rio Pandeiros - MG & 40 & 29 & 17 & 19 \\
Delfinópolis - MG & 22 & 19 & 15 & Present study \\
Santa Rita do Passa Quatro - SP & 36 & 24 & 11 & Urso-Guimarães \& Scareli-Santos (2006) \\
Campus Pampulha - MG & 37 & 22 & 21 & Fernandes et al. (1988) \\
Serra do Cabral - MG & 47 & 39 & 21 & Coelho et al. (2013) \\
Caldas Novas - G0 & 56 & 34 & 28 & Santos et al. (2012) \\
Estação Ecológica de Pirapitinga -MG & 92 & 62 & 24 & Gonçalves-Alvim \& Fernandes (2001) \\
Parque Nacional das Emas - G0 & 97 & 44 & 73 & 30 \\
Serra de São José - MG & 137 & & Araújo et al. (2014b)
\end{tabular}

dardized measure of galling species per plant species obtained in the present study (1.37) can also be considered intermediate. In a recent review, Araújo et al. (2019b) founded that the mean number of insect gall morphotypes per plant species for Brazilian inventories was 1.72 $( \pm 0.43)$, ranging between 1.16 and 3.50 .

Gall-inducing arthropod fauna recorded in the EPA of Rio Pandeiros was composed of distinct and important galling groups such as gall-midges (Cecidomyiidae) and eriophyids (Eriophyidae), which induced $85 \%$ and $7.5 \%$ of the gall morphotypes, respectively. Gall-midges are the largest and most diverse group of galling insects in the world (Gagné, 2014). In gall surveys conducted in Brazil this family has shown to be quite diverse and abundant (review in Araújo et al., 2019b). Eriophyids are galling mites than can induce galls in more than 500 host plant species (Petanovíc \& Kielkiewicz, 2010). In Brazil eriophyids are rarely include in gall inventories, but in other parts of globe some studies have highlighted the importance of the group for galling fauna (e.g., Nasareen \& Ramani, 2014; Araújo et al., 2019a). According review of Maia (2006) gall-inducing insects of the orders Hemiptera and Lepidoptera are less common in the Neotropical region, which corroborates the results of the present study where these groups represented less of $8 \%$ of gall-inducers.

The plant family with higher gall richness was Fabaceae with 16 morphotypes, being this also the family with the largest number of host species (eight in total). The recent review about Brazilian gall inventories points that Fabaceae is the most important host family of Brazil, appearing as a super-host in $68.6 \%$ of the studies (Araújo et al., 2019b). The great intrinsic galling insect richness of this plant family may be due to the great diversity of species it presents (Mendonça, 2007). The host-plant species with higher diversity of gall morphotypes also were of family Fabaceae: Copaifera oblongifolia and Andira humilis. Recent studies have pointed Copaifera oblongifolia (Fabaceae) as a super-host plant of galling insects with 15 different gall morphotypes recorded (Coutinho et al., 2019; Fagundes et al., 2019b). Species of the genus Andira have also been listed as important hosts of galling insects in other areas of neotropical savannas, such as Andira paniculata Benth. (Santos et al., 2012).

Contrary to the expected the galling species richness was not affected by plant species richness and abundance of super host plants, despite the tendency of a positive effect of the abundance of Copaifera oblongifolia on the arthropod gall richness. A possible explanation for these results may be environmental factors, such as environmental stress and soil fertility, which were not measured in the present study, but may also influence the distribution of galling species (Gonçalves-Alvim \& Fernandes, 2001; Ramos et al., 2019). On the other hand, we found that galling species per plant species was negatively affected by plant species richness and positively affected by abundance of super-host plants, corroborating our expectations. The negative relationship between plant species richness and galling species per plant species likely is a mathematical effect of increment in the number of host plant species (denominator) more accelerated than the number of galling species (numerator). However, the positive effect of the abundance of super-host plants on this measure may be indicative that each individual of Copaifera oblongifolia add new species of galling species to the community. Our results highlight the importance of super-host plants for galling arthropod diversity on a local scale, corroborating previous studies (e.g., Araújo et al., 2014a).

This is the first study of arthropod-induced galls conducted in EPA of Rio Pandeiros, Minas Gerais, Brazil. Considering that our sampling was done through a rapid 
ecological study, medium- and long-term sampling, considering different seasonal periods, will probably result in the recording of a greater diversity of arthropod galls. Nevertheless, compared to other areas of cerrado sensu stricto in Brazil the diversity recorded in the present study can be considered intermediate. Previous studies have shown that different factors can affect the diversity of gall-inducing arthropods in Neotropical savannas (Gonçalves-Alvim \& Fernandes, 2001; Araújo et al., 2013; Araújo et al., 2014a). Contrary to expectations, we did not find effects of the plant species richness and abundance of super-host plants on the galling species richness but found that these explanatory variables affected significantly the number of galling species per plant species. Thus, we believe that future studies can investigate the extent to which the occurrence of other super-host species influences the local diversity of galling arthropods.

\section{ACKNOWLEDGMENTS}

The authors are thankful to the CAPES-Brazil for the grants to LTS and EVDF and to CNPq (306375/2016-8) and FAPEMIG (CRA-PPM-00627-16) for productivity grants to YRF Nunes. We thank the CNPq/FAPEMIG-Brazil by supported to search by PELD-VERE (CNPq 441440/2016-9; CAPES 88887.136273/2017-00; FAPEMIG APQ-04816-17). This study was conducted during the field course of discipline "Ecologia do Cerrado" from the PPG-BURN and PPG-BOT/UNIMONTES.

\section{AUTHOR'S CONTRIBUTIONS}

All authors participated in the field data collection. The laboratory procedures were made by Kelly Christie dos Santos Costa, Luana Teixeira Silveira and Érica Vanessa Durães de Freitas. The analyzes were performed by Walter Santos de Araújo. All authors participated in the writing of the manuscript.

\section{REFERENCES}

Altamirano, A.; Valladares, G.; Kuzmanich, N. \& Salvo, A. 2016. Galling insects in a fragmented forest: incidence of habitat loss, edge effects and plant availability. Journal of Insect Conservation, 20(1): 119-127.

Alvares, C.A.; Stape, J.L.; Sentelhas, P.C.; Gonçalves, J.L.M. \& Sparovek, G. 2013. Köppen's climate classifcation map for Brazil. Meteorologische Zeitschrift, 6: 711-728.

Araújo, W.S. 2013. Different relationships between galling and nongalling herbivore richness and plant species richness: a meta-analysis. Arthropod-Plant Interactions, 7(4): 373-377.

Araújo, W.S.; Scareli-Santos, C.; Guilherme, F.A.G. \& Cuevas-Reyes, P. 2013. Comparing galling insect richness among Neotropical savannas: effects of plant richness, vegetation structure and super-host presence. Biodiversity and Conservation, 22: 1083-1094.

Araújo, W.S.; Cuevas-Reyes, P. \& Guilherme, F.A.G. 2014a. Local and regional determinants of galling-insect richness in Neotropical savanna. Journal of Tropical Ecology, 30(3): 269-272.
Araújo, W.S.; Sobral, F.L. \& Maracahipes, L. 2014b. Insect galls of the Parque Nacional das Emas (Mineiros, G0, Brazil). Check List, 10(6): 1445-1451.

Araújo, W.S.D.; Freitas, É.V.D.D.; Kollár, J.; Pessoa, R.O.; Corgosinho, P.H.C.; Valério, H.M.; Falcão, L.A.D.F.; Fagundes, M.; Pimenta, M.A.S.; Faria, M.L.; Borges, M.A.Z. \& Martins, W.P. 2019a. Host Specialization in Plant-galling Interactions: Contrasting Mites and Insects. Diversity, 11(10): 180.

Araújo, W.S.; Fernandes, G.W. \& Santos, J.C. 2019b. An overview of inventories of gall-inducing insects in Brazil: looking for patterns and identifying knowledge gaps. Anais da Academia Brasileira de Ciências, 91(1): 1-19, e20180162.

Bahia, T.D.O.; Luz, G.R.; Braga, L.L.; Menino, G.C.0.; Nunes, Y.R.F.; Veloso, M.D.M.; Neves, W.V. \& Santos, R.M. 2009. Florística e fitossociologia de veredas em diferentes estágios de conservação na APA do Rio Pandeiros, norte de Minas Gerais, MG. Biota, Belo Horizonte, 2(3): 14-21.

Blanche, K.R. 2000. Diversity of insect-induced galls along a temperaturerainfall gradient in the tropical savannah region of the Northern Territory, Australia. Austral Ecology, 25: 311-318.

Carneiro, M.A.A.; Branco, C.S.A.; Braga, C.E.D.; Almada, E.D.; Costa, M.B.M.; Maia, V.C. \& Fernandes, G.W. 2009. Are gall midge species (Diptera, (ecidomyiidae) host-plant specialists? Revista Brasileira de Entomologia, 53(3): 365-378.

Coelho, M.S.; Carneiro, M.A.A.; Branco, C.A. \& Fernandes, G.W. 2013. Gallinducing insects from Serra do Cabral, Minas Gerais, Brazil. Biota Neotropical, 13: 102-109.

Costa, F.V.D.; Fagundes, M. \& Neves, F.S. 2010. Arquitetura da planta e diversidade de galhas associadas à Copaifera langsdorffii (Fabaceae). Ecología Austral, 20: 9-17.

Costa, K.C.D.S. \& Araújo, W.S. 2019. Distribution of gall-inducing arthropods in areas of deciduous seasonal forest of Parque da Sapucaia (Montes (laros, MG, Brazil): effects of anthropization, vegetation structure and seasonality. Papéis Avulsos de Zoologia, 59(31): 1-10.

Coutinho, R.D.; Cuevas-Reyes, P.; Fernandes, G.W. \& Fagundes, M. 2019. Community structure of gall-inducing insects associated with a tropical shrub: regional, local and individual patterns. Tropical Ecology, 60(1):74-82.

Cuevas-Reyes, P.; Quesada, M.; Hanson, P.; Dirzo, R. \& Oyama, K.E.N. 2004. Diversity of gal-inducing insects in a Mexican tropical dry forest: the importance of plant species richness, life-forms, host plant age and plant density. Journal of Ecology, 92: 707-716.

Drummond, G.M.; Martins, C.S.; Machado, A.B.M.; Sebaio, F.A. \& Antonini, Y. 2005. Biodiversidade em Minas Gerais: um atlas para sua conservação. 2.ed. Belo Horizonte, Fundação Biodiversitas. 222p.

Empresa Brasileira de Pesquisa Agropecuária (EMBRAPA). 2013. Sistema brasileiro de classificação de solos. 3.ed. Brasília, EMBRAPA. 353p.

Fagundes, N.C.A.; Ávila, M.A.; Souza, S.R.; Azevedo, I.F.P.; Nunes, Y.R.F.; Fernandes, G.W.; Fernandes, L.A.; Santos, R.M. \& Veloso, M.D.M. 2019a. Riparian vegetation structure and soil variables in Pandeiros river, Brazil. Rodriguésia, 70: 1-13, e0182017.

Fagundes, M.; Barbosa, E.M.; Oliveira, J.B.; Brito, B.G.; Freitas, K.T.; Freitas, K.F. \& Reis-Junior, R. 2019b. Galling inducing insects associated with a tropical shrub: The role of resource concentration and species interactions. Ecología Austral, 29(01): 012-019.

Fernandes, G.W.; Carneiro, M.A. \& Isaias, R.M. 2014. Gall-inducing insects: From anatomy to biodiversity. In: Panizzi, A.R. \& Parra, J.R.P. (Eds.). Insect bioecology and nutrition for integrated pest management. Boca Raton, FL. p. 369-395.

Fernandes, G.W.; Carneiro, M.A.A.; Lara, A.C.F.; Allain, L.R.; Andrade, G.I.; Julião, G.R.; Reis, T.R. \& Silva, I.M. 1996. Galling insects on neotropical species of Baccharis (Asteraceae). Tropical Zoology, 9: 315-332.

Fernandes, G.W.; Tameirão-Neto, E. \& Martins, R.P. 1988. Ocorrência e caracterização de galhas entomógenas na vegetação do Campus 
Pampulha da Universidade Federal de Minas Gerais. Revista Brasileira de Zoologia, 5: 11-29.

Gagné, R.J. 2014. Update for a catalog of the Cecidomyiidae (Diptera) of the world. Digital version. 3.ed. Available at: http://www.ars.usda.gov. Access in: 03/13/2019.

Gonçalves-Alvim, S.J. \& Fernandes, G.W. 2001. Biodiversity of galling insects: historical, community and habitat effects in four neotropical savannas. Biodiversity \& Conservation, 10(1): 79-98.

Isaias, R.M.D.S.; Carneiro, R.G.S.; Oliveira, D.C. \& Santos, J.C. 2013. Illustrated and annotated checklist of Brazilian gall morphotypes. Neotropical Entomology, 42(3): 230-239.

Maia, V.C. 2006. Galls of Hemiptera, Lepidoptera e Thysanoptera from Central and South America. Publicações Avulsas do Museu Nacional, 110: 1-24.

Maia, V.C. \& Fernandes, G.W. 2004. Insect galls from Serra de São José (Tiradentes, MG, Brazil). Brazilian Journal of Biology, 6: 423-445.

Mendonça, M.S. 2007. Plant diversity and galling arthropod diversitysearching for taxonomic patterns in an animal-plant interaction in the Neotropics. Boletin de la Sociedad Argentina de Botanica, 42: 347-357.

Miller III, D.G. \& Raman, A. 2019. Host-Plant Relations of Gall-Inducing Insects. Annals of the Entomological Society of America, 112: 1-19.

Nasareen, P.N.M. \& Ramani, N. 2014. Survey on gall forming Eriophyid Mites (Acari: Eriophyidae) associated with economically important plants of North Kerala. Journal of Entomology and Zoology Studies, 2(5): 126-133.

Petanovíc, R. \& Kielkiewicz, M. 2010. Plant-eriophyoid mite interactions: specific and unspecific morphological alterations. Part II. Experimental and Applied Acarology, 51: 81-91.

Price, P. 2002. Resource-driven terrestrial interaction webs. Ecological Research, 17: 241-247.
R Development Core Team. 2015. R: a language and environment for statistical computing. Vienna, R Foundation for Statistical Computing.

Ramos, L.F.; Solar, R.R.; Santos, H.T. \& Fagundes, M. 2019. Variation in community structure of gall-inducing insects associated with a tropical plant supports the hypothesis of competition in stressful habitats. Ecology and Evolution, 9(24): 13919-13930.

Ribeiro, A.N.; Balbi, M.I.P. \& Urso-Guimarães, M.V. 2019. Characterization of insect galls from a vegetation area in Altinópolis, São Paulo State, Brazil. Papéis Avulsos de Zoologia, 59(4): 1-9, e20195904.

Santos, B.B.; Ribeiro, B.A.; Silva, T.M. \& Araújo, W.S. 2012. Galhas de insetos em uma área de cerrado sentido restrito na região semi-urbana de Caldas Novas (Goiás, Brasil). Revista Brasileira de Biociências, Porto Alegre, 10(4): 439-445.

Urso-Guimarães, M.V. \& Scareli-Santos, C. 2006. Galls and gall makers in plants from Pé-de-Gigante Cerrado Reserve, Santa Rita do Passa Quatro, SP, Brazil. Brazilian Journal of Biology, 66, 357-369.

Urso-Guimarães, M.V.; Scareli-Santos, C. \& Bonifácio-Silva, A.C. 2003. Occurrence and characterization of entomogen galls in plants from natural vegetation areas in Delfnópolis, MG, Brazil. Brazilian Journal of Biology, 63: 705-715.

Veldtman, R. \& Mcgeoch, M.A. 2003. Gall-forming insect species richness along a non-scleromorphic vegetation rainfall gradient in South Africa: the importance of plant community composition. Ecological Society of Australia, 28: 11-13.

Wright, M.G. \& Samways, M.J. 1998. Insect species richness tracking plant species richness in a diverse flora: gall-insects in the Cape Floristic Region, South Africa. Oecologia, 115: 427-433. 